Original article DOI: $10.19027 /$ jai.17.1.26-33

\title{
The effectiveness of pen-culture construction for cultivation of sea cucumber
}

\section{Efektivitas konstruksi kurungan tancap untuk budidaya teripang}

\author{
Pitjont Tomatala $^{1^{*}}$, Petrus Paulus Letsoin*, Evangelin Martha Yulia Kadmaer ${ }^{*}$ \\ Study Program of Aquaculture Technology, Tual State Polytechnic of Fisheries \\ Southeast Maluku, Indonesia \\ *E-mail:pitjont_82@yahoo.com
}

(Received 14 September 2017; Accepted 21 Februari 2018)

\begin{abstract}
Sea cucumber Holothuria sp. is a marine biota that has economic value. The rearing activity of sea cucumbers is still limited to the have bay or strait areas with relatively calm coastal. This research aimed to determine the effectiveness of two types of pen-culture system for sea cucumber rearing to the influence of ocean waves and currents. This research was done from February to July 2017 in the coastal of Rat village, Southeast Maluku Regency. The two of cultivated containers tested were a conventional pen-culture (treatment A) and engineered pen-culture (treatment B). A total of 30 individuals sea cucumber seeds sized 4-6 cm were released at each penculture. Survival rate and water quality were also calculated as supporting data. Observation of endurance and clearance of pen-culture was done every two weeks. The result of visual observation showed that conventional pen-culture treatment A was more quickly damaged and it was more damaged compared to engineered penculture treatment $\mathrm{B}$. Through $\mathrm{t}$-test we got $\mathrm{T}_{\text {count }}(1.065)<\mathrm{T}_{\text {table }}(6.313)$ for survival and $\mathrm{T}_{\text {count }}(0.084)<\mathrm{T}_{\text {table }}(1.782)$ for growth. The result means that treatment $\mathrm{A}$ and treatment $\mathrm{B}$ have the same effect on survival rate and growth of sea cucumber. The results showed that treatment B was better applied to more open waters than treatment A.
\end{abstract}

Keywords: endurance, pen-culture, sea cucumber, survival, growth

\begin{abstract}
ABSTRAK
Teripang Holothuria sp. merupakan biota laut yang memiliki nilai ekonomis. Kegiatan budidaya teripang masih terbatas pada daerah-daerah yang berteluk atau berselat dengan perairan yang relatif tenang. Penelitian ini bertujuan untuk membandingkan efektivitas dua sistem budidaya teripang dalam kurungan tancap terhadap pengaruh gelombang laut dan arus. Penelitian ini berlangsung dari bulan Februari hingga Juni 2017 di perairan Desa Rat, Kabupaten Maluku Tenggara. Dua tipe wadah budidaya yang diujicobakan adalah kurungan tancap konvensional (perlakuan A) dan kurungan tancap yang direkayasa (perlakuan B). Pada setiap kurungan tancap, dimasukkan teripang pasir berukuran 4-6 cm sebanyak 30 ekor. Sebagai data pendukung, dihitung persentase kelangsungan hidup dan pengukuran kualitas air. Pengamatan ketahanan dan kebersihan kurungan tancap dilakukan setiap dua minggu sekali. Hasil pengamatan visual diketahui bahwa kurungan tancap perlakuan A lebih cepat rusak dan mengalami kerusakan yang lebih besar dibandingkan perlakuan B. Melalui uji-t diperoleh hasil $\mathrm{T}_{\text {hitung }}(1,065)<$ $\mathrm{T}_{\text {tabel }}(6,313)$ untuk kelangsungan hidup, dan $\mathrm{T}_{\text {hitung }}(0,084)<\mathrm{T}_{\text {tabel }}(1,782)$ untuk pertumbuhan. Hasil uji-t bermakna bahwa perlakuan A dan perlakuan B memiliki pengaruh yang sama terhadap kelangsungan hidup dan pertumbuhan teripang. Hasil pengamatan menunjukkan bahwa perlakuan B lebih baik diaplikasikan pada perairan yang lebih terbuka dibandingkan perlakuan A.
\end{abstract}

Kata kunci: ketahanan, kurungan tancap, teripang, kelangsungan hidup, pertumbuhan 


\section{INTRODUCTION}

Sea cucumber is aquatic invertebrate animals belong to Holothuria class. The species of sea cucumber has a high economic value and very prospective in both domestic and international market. The market price of the sea cucumber is around IDR 400,000 until IDR 1,200,000,-/ $/ \mathrm{kg}$ dry weight. Sea cucumbers are nutritious seafood with high protein content and low lipids and rich in gluten, nitrogen, and iodine. Therefore, it is one of the reasons many sea cucumbers were caught and used as raw materials food and drugs ingredients (Azam \& Singh, 2013).

Southeast Maluku Regency is inhabited by several types of marine biodiversity, one of most important one is sea cucumbers. Utilization of sea cucumbers in the area of Southeast Maluku is more dominated by catching sea cucumbers in nature compared to rearing activities, though caught in nature continues to decrease in number and size. On the other hand, the coastal site in this area is decorated with the ecosystem of seagrass and coral reef which is wide and can be used as rearing area of sea cucumber. But practically, rearing activity of sea cucumber has not been done many by society in Southeast Moluccas Regency as one the source of society income.

Rearing activity of sea cucumber (seed rearing until the market size) what society does very limited to areas have bay and the social ability itself. Type of sea cucumbers which were reared is sand cucumber, Holothuria scabra. Rearing activity of $H$. scabra is still centrally in the bay area. It is caused by construction of farm container used (pen-culture) much-permeating wind and waving so when placed on the area without any bay and have strait will be easy to damage. On the other hand, the habitat of sea cucumber found in Southeast Moluccas which potentially used as rearing area of sea cucumber is in coastal where is more open and has no bay. This research was instructed to determine the resistance of container rearing sea cucumber (pen-culture) to the influence of waves and ocean current.

\section{MATERIALS AND METHODS}

\section{Time and place}

This research was conducted for six months from February to July 2017 and located at Rat village, Southeast Moluccas Regency (coordinate point of South 0550'43,1" and East 13248'53,6"). The coastal of Rat Village was chosen as an experimental location because their habitat is very suitable for sand cucumbers, the village has a sloping water base and there is also a natural wave's barrier in the tide limits.

\section{Research design}

The pen-culture was experimented with two treatments. Treatment A: conventional penculture sized $3 \mathrm{~cm}$ long, $2 \mathrm{~cm}$ wide, and high above the water depth at highest tide (Figure 1a), and treatment $\mathrm{B}$ : engineered pen-culture sized 3 $\mathrm{m}$ length, $2 \mathrm{~m}$ wide, and $0.6 \mathrm{~m}$ high (Figure $1 \mathrm{~b}$ ). In treatment $\mathrm{B}$, pen-culture using a cover made of the net which aims to prevent sea cucumbers released to open water or disruption from the environment outside pen-culture. Each treatment was repeated three times and sea cucumber seed size $4-6 \mathrm{~cm}$ were released as much as 30 individuals.

The pen-culture made of wood plugged in the substrate as deep $40-50 \mathrm{~cm}$. The left and right sides of the wood stuck were excavated 30-40 $\mathrm{cm}$ and net (mesh size $1 \mathrm{~mm}$ ) was embedded in the excavation as a guardrail. Cleaning and observation of the pen-culture condition were done every two weeks.
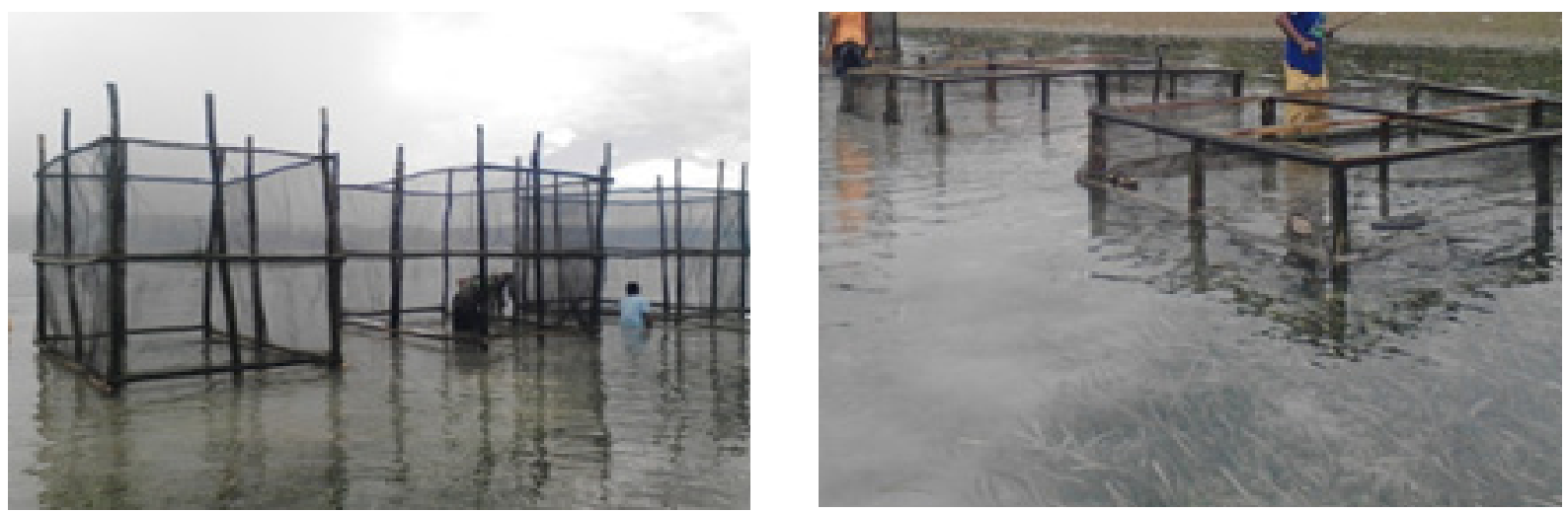

Figure 1. The construction of pen-culture for sea cucumber rearing $(\mathrm{a}=$ treatment $\mathrm{A}, \mathrm{b}=$ treatment $\mathrm{B})$ 


\section{Variables and measurement method}

The variables observed in this research were the endurance of pen-culture, the calculation of survival, and growth rate. The observation of the endurance construction was done by observing the endurance of materials (wood and net) used in making pen-culture. Observation of the endurance construction was done every two weeks. At the same time, survival calculations were performed by counting all individuals on both treatments. The measurement of growth and water quality (temperature, salinity, the dissolved oxygen, the degree of acidity/pH, measurement of current strength, wave, and brightness) were done every two weeks as supporting data.

\section{Data analysis}

The resistance data of pen-culture was analyzed qualitatively while the survival rate and growth rate data were analyzed quantitatively.

The survival rate is calculated based on the equation:

$$
\mathrm{S}=\mathrm{N}_{\mathrm{t}} / \mathrm{N}_{\mathrm{o}} \times 100
$$

Note:

S : Survival rate (\%)

$\mathrm{N}_{\mathrm{t}} \quad$ : Final number of individual experiments

No : Initial number of individual experiments

The absolute growth is calculated based on the equation:

$$
\begin{aligned}
& \mathrm{W}=\mathrm{W}_{\mathrm{t}}-\mathrm{W}_{0} \\
& \text { Note: } \\
& \mathrm{W}: \text { Absolute growth }(\mathrm{g}) \\
& \mathrm{Wt}: \text { Final wet weight }(\mathrm{g}) \\
& \mathrm{Wo}: \text { Initial wet weight }(\mathrm{g})
\end{aligned}
$$

To find out the difference between the two pen-culture treatments, the data of survival and growth was analyzed by using t-test. Statistical testing was performed using excel 2007 program.

\section{RESULTS AND DISCUSSION}

\section{Endurance of construction}

The pen-culture is a cultivated area that is fenced like a cage so that the sea cucumber cannot escape. Conditions of the pen-culture endurance that was experimented for 4 months of observation are shown in the following Table 1 .

In the Table 1 can be read that the rearing container began to be damaged in April. This was because of the East Season, wherein the area of research experienced a physical strike of the waters. In Southeast Maluku Regency, there is

\begin{tabular}{|c|c|c|}
\hline \multirow{2}{*}{$\begin{array}{c}\text { Time } \\
\text { observation }\end{array}$} & \multicolumn{2}{|c|}{ Condition of pen-culture } \\
\hline & Treatment A & Treatment B \\
\hline February & - Making of rearing container & - Making of rearing container \\
\hline March & $\begin{array}{l}\text { - Strong wood construction } \\
\text { - All sides of the net have been stuck with } \\
\text { moss. }\end{array}$ & $\begin{array}{l}\text { - Strong wood construction } \\
\text { - All sides of the net have been stuck with } \\
\text { moss. }\end{array}$ \\
\hline April & $\begin{array}{l}\text { - Strong wood construction } \\
\text { - The moss file attached to the net started } \\
\text { to appear even though it has been cleaned } \\
\text { (brushed) } \\
\text { - The net was started to tear apart on the part } \\
\text { faces the coming current and wave }\end{array}$ & $\begin{array}{l}\text { - Strong wood construction } \\
\text { - The moss attached to the net started to } \\
\text { appear even though it has been cleaned } \\
\text { (brushed) } \\
\text { - The pen-culture was not damaged }\end{array}$ \\
\hline May & $\begin{array}{l}\text { - Strong wood construction } \\
\text { - The front net which faced the current and } \\
\text { backside of the pen-culture began to detach }\end{array}$ & $\begin{array}{l}\text { - Strong wood construction } \\
\text { - The pen-culture was not damaged }\end{array}$ \\
\hline June & $\begin{array}{l}\text { - Strong wood construction } \\
\text { - The net in the front and back of pen-culture } \\
\text { detached. } \\
\text { - Replaced the damaged net }\end{array}$ & $\begin{array}{l}\text { - Strong wood construction } \\
\text { - Starting to look small tears in the area of } \\
\text { net connection but only one pen-culture. }\end{array}$ \\
\hline July & $\begin{array}{l}\text { - Strong wood construction } \\
\text { - Small tears started to form in the area of net } \\
\text { connection. }\end{array}$ & $\begin{array}{l}\text { - Strong wood construction } \\
\text { - There was a small tear in the net } \\
\text { connection area but only one pen-culture. }\end{array}$ \\
\hline
\end{tabular}
two wind-blowing seasons of the year, East and West seasons. The East season runs from April to October, while the West season runs from October to April. In the East Season, there will

Table 1. Observation result endurance of construction 
Table 2. The advantages and disadvantages of each treatment

\begin{tabular}{|c|c|c|}
\hline Observation & Treatment A & Treatment B \\
\hline $\begin{array}{l}\text { Material use (wood, bamboo } \\
\text { hemispheres, and nails) }\end{array}$ & Used numerous material & $\begin{array}{l}\text { Use of material for treatment B } 1 / 2 \\
\text { less than material treatment A }\end{array}$ \\
\hline To pointed wood stick & $\begin{array}{l}\text { Needed } 1-2 \text { people to point a } \\
\text { wood stick }\end{array}$ & $\begin{array}{l}\text { Only one person needed to point a } \\
\text { wood stick }\end{array}$ \\
\hline Stict wood on the substrate & $\begin{array}{l}\text { Needed } 3-4 \text { people to stick a wood } \\
\text { on the substrate }\end{array}$ & $\begin{array}{l}\text { Needed } 1-2 \text { people to stick a wood } \\
\text { on the substrate }\end{array}$ \\
\hline $\begin{array}{l}\text { Observation of the mounting point } \\
\text { of pen-culture }\end{array}$ & $\begin{array}{l}\text { It took more time to observe the } \\
\text { lowest and highest tide }\end{array}$ & $\begin{array}{l}\text { Time was only needed to observe the } \\
\text { lowest tide }\end{array}$ \\
\hline Stocking of sea cucumber & $\begin{array}{l}\text { Could be done at low tide and high } \\
\text { tide. At high tide beyond the height } \\
\text { of humans by swimming }\end{array}$ & $\begin{array}{l}\text { Can be done only at low tide. At high } \\
\text { tide above human height, needed } \\
\text { extra effort (swimming and diving) } \\
\text { to stock sea cucumbers in rearing } \\
\text { containers }\end{array}$ \\
\hline Control of sea cucumbers & $\begin{array}{l}\text { - Controlling is easier to be done } \\
\text { at low tide } \\
\text { - Control during high tide can be } \\
\text { done directly by using a mask } \\
\text { and snorkel }\end{array}$ & $\begin{array}{l}\text { - Controlling is easier to be done at } \\
\text { low tide } \\
\text { - Control during high tide can be } \\
\text { done by diving and open the cover } \\
\text { of the pen-culture to observe } \\
\text { from the water surface by using a } \\
\text { mask and snorkel }\end{array}$ \\
\hline
\end{tabular}

be a breeze of East and Southeast as much as $91 \%$ with a dominant $61 \%$ southeast wind (Bapeda, 2016).

In Table 1 it is seen that treatment $\mathrm{A}$ is more rapidly damaged (April) and worse than what happened to the treatment $\mathrm{B}$. This condition occurred because the treatment A construction is higher than the treatment B so that treatment A is more exposed by wind, waves, and currents. The tolerance range of current velocity and wave height for sea rearing are $5-40 \mathrm{~cm} / \mathrm{sec}$ and 0.6-1 m (Adipu et al., 2013; Windupranata, 2007). During the research, the advantages and disadvantages of each treatment were observed. The advantages and disadvantages are shown in Table 2 .

The wind caused the sea waves and water currents that hit the rearing container continuously. According to Risandi et al. (2015), the major cause of the wave is the wind. In addition, sea waves can also be caused by earthquakes, volcanic eruptions, underwater landslides (tsunami), and the gravity between the earth and moon which caused permanent sea waves, known as tidal waves (Loupatty, 2013). The damage which occurred to the rearing of sea cucumber that is experimented was assumed to occur due to sea wave and current factor caused by wind blowing in East Season. This assumption was reinforced because during the time period of research, no other natural phenomena that caused the occurrence of massive sea waves due to wind and tidal. For the tides observed that before the East Season (February-March), sea waves during tides occur not as strong as the East Season (April-July). Strong current and wave data can be seen in Table 3.

\section{Survival rate}

Survival is the amount that remains alive according to the unit of time or the percentage of individuals living against the total number of individuals (Tomatala, 2014). The results of the survival rate calculation of sea cucumber during the research on both treatments are shown in Figure 2.

In Figure 2 it can be seen that the survival rate of sea cucumber in both containers was decreased from week 4 to week 20. The presence of crabs in rearing containers was assumed to affect the value of survival. Lavitra et al. (2009) state that crabs, shrimp, gastropods, and fish from the family Siganidae are predators for sea cucumbers. Added also by Namukose et al. (2016) that crustaceans, especially crabs, are organisms that endanger the survival of sea cucumbers. At week 10 , there were juvenile crabs on the pen-culture in both treatments. The presence of crab seedlings in treatment $\mathrm{A}$ was assumed to be caused by the net as a cage safety. While in treatment B, the 
presence of crabs was caused by the cover of the pen-culture was opened entirely at the time of counting the surviving seed. Hair et al. (2016) state that net using in pen-culture succeeded in reducing predation by large predators. Besides, the death of seed sea cucumber was caused by the availability of food. Sea cucumbers were not given additional feed, so that sea cucumbers were difficult to obtain food. By lacking food intake, sea cucumbers can easily exposed to deadly infectious disease.

In Figure 2 it is also seen that the value of survival rate fluctuated at $12^{\text {th }}$ week to $20^{\text {th }}$ week. This is because at the time of harvesting sea cucumber, the rearing media experienced high turbidity and it as worsen by the low tide caused difficulties in collecting sea cucumbers. In addition, the harvesting of sea cucumbers was also done during the day, where the cucumber in the afternoon more passive and immersing themselves into the sand also caused some difficulties to collect sea cucumbers. According to Sulardiono and Hendrarto (2014), sea cucumbers belong to nocturnal animals which active at night. They appear to surface substrates for food and reproduction activities, while in the daytime, sea cucumbers stay dwelled and immersed in the sand.

The average survival of sea cucumbers maintained at both treatments amounted to 58.8$60.0 \%$. Lavitra et al. (2010) reported that the survival of seed sea cucumber maintained in pen-culture or sea pens can reach $75 \%$, while Serang et al. (2016) reported that the survival rate of sea cucumber cultivated in pen-culture during August-October in Ngilngof coastal of Southeast Maluku Regency was 93.3-96.6\%. The results of the survival rate obtained from this study were relatively low when compared with the results of both researchers. Purcell (2012) explained that the survival of sea cucumbers juvenile maintained in nature varies greatly. Furthermore, Agudo (2012) confirmed that the survival rate of sea cucumbers juvenile kept in nature without predators ranged from $40-85.0 \%$.

Through the $\mathrm{t}-$ test obtained result $\mathrm{T}_{\text {count }}(1.065)$ $<\mathrm{T}_{\text {table }}$ (6.313). The value obtained indicates that both the rearing construction of rearing container treatment performed the same effect on the survival rate of sea cucumber.

\section{Growth}

The weight of the sea cucumber is used as an indicator of growth. The results of the weight measurement of sea cucumber during the research took place shown in Figure 3. Figure 3 showed that sea cucumbers were weighted for six months in which treatment A experienced an absolute growth of $14.8 \mathrm{~g}$ and treatment B of $14.9 \mathrm{~g}$. Serang et al. (2016) reported that weight growth of sea cucumbers $H$. scabra could reach 11.1-12.2 g for two months of rearing. This means that the growth of sea cucumbers in this research was relatively slow. Slow growth of sea cucumber was assumed to occur due to the lack of food availability during the rearing period.

Food is an external factor that affects the growth of biota living in the tropics. The lack of

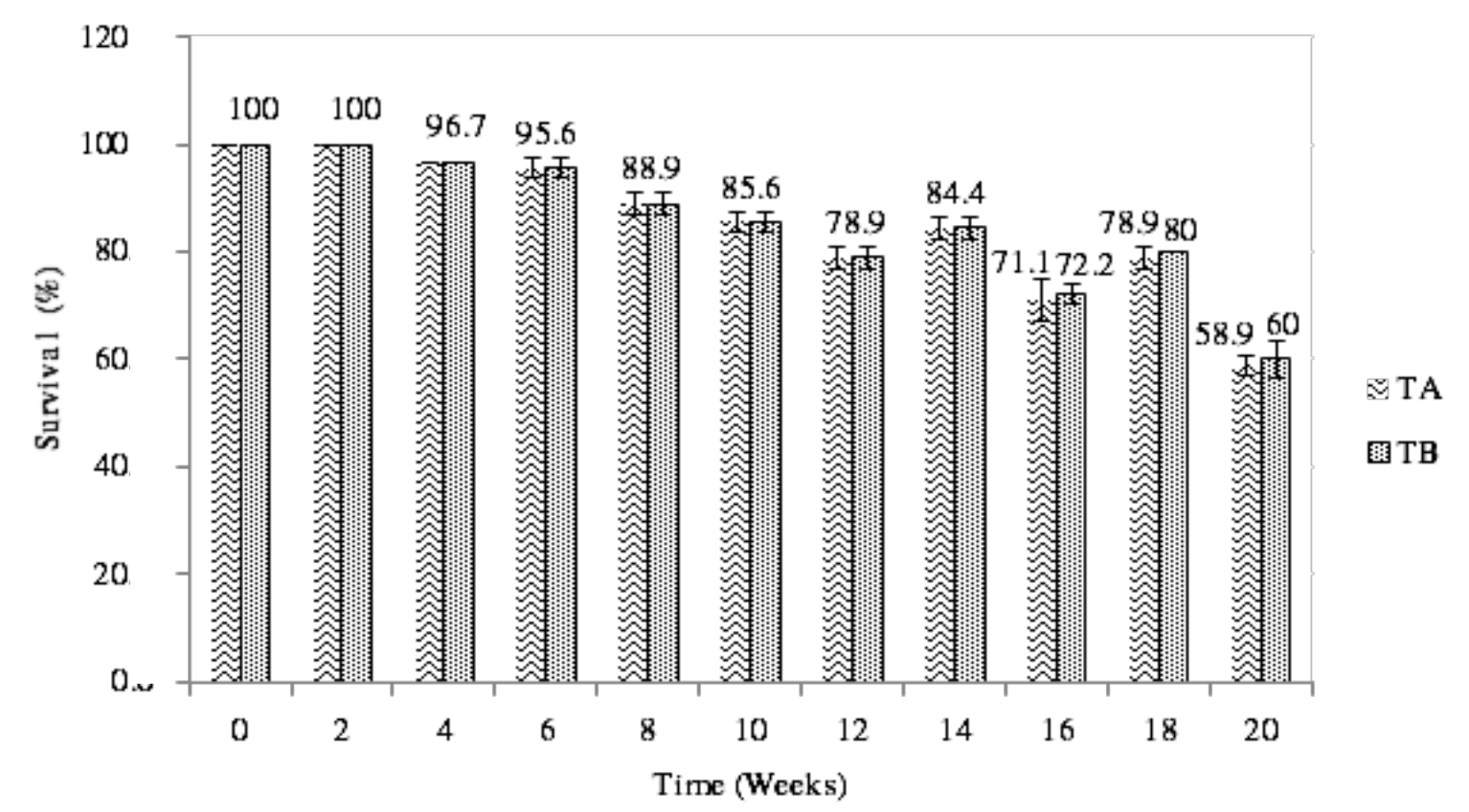

Figure 2. Survival rate of sea cucumber during the experiment on TA (treatment A) and TB (treatment B) 


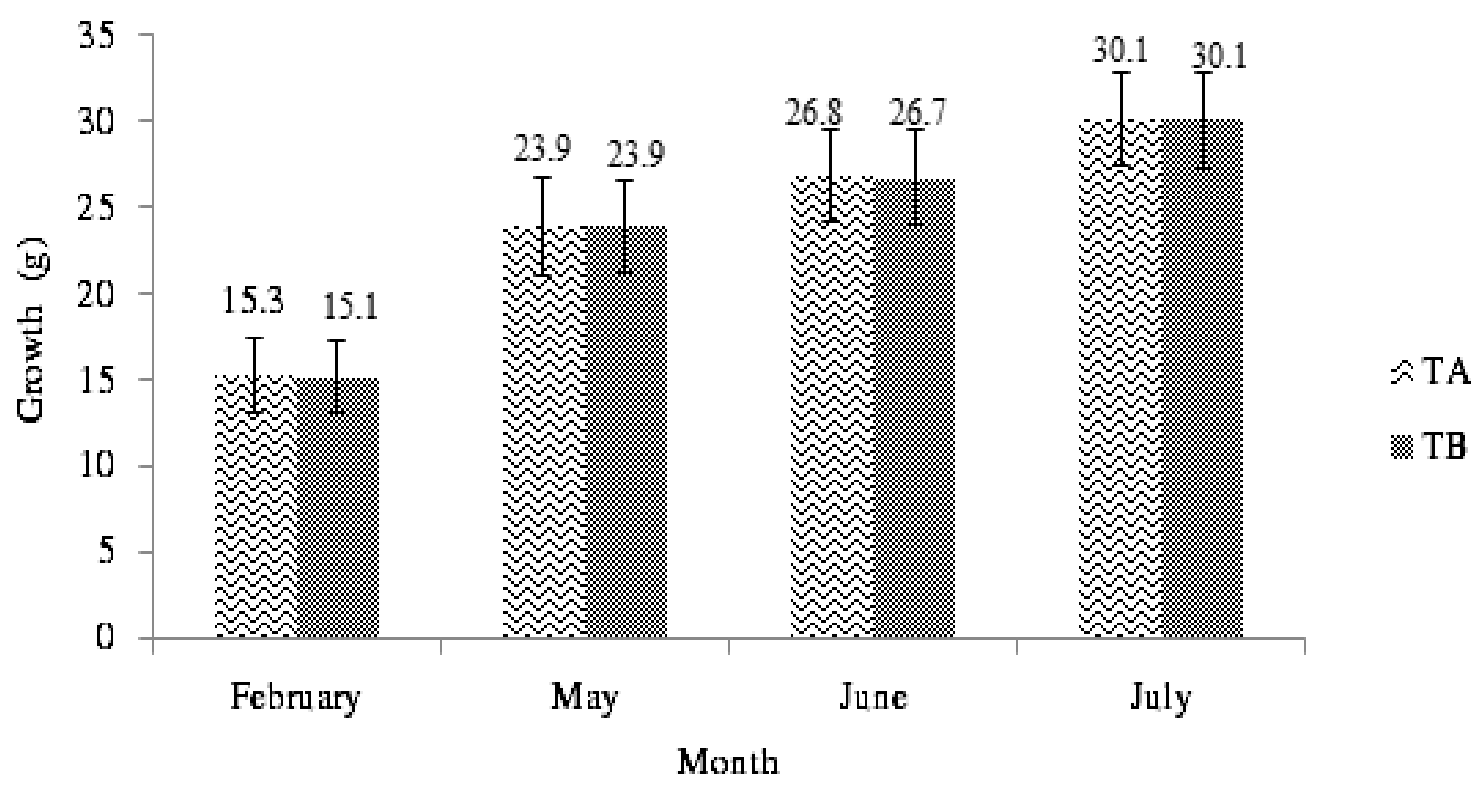

Figure 3. Growth of sea cucumber reared in pen-culture

food availability and high-density stocking cause sea cucumbers had difficulties to get food so that interferes with the growth of sea cucumbers. In this research, the density did not affect slow growth because the density at the time of the research was only 30 individuals in the culture of $3 \times 2$ meters. According to Padang et al. (2017), the ideal cucumber density on the cultivation container is 10 individuals $/ \mathrm{m}^{2}$.

The lack of food availability in pen-culture because the sea cucumber was not given additional feed. Additional feeding aimed to provide feed for sea cucumbers which maintained, but also enrich substrates that can stimulate the growth of the organisms eaten sea cucumbers. An indicator of the lack of food availability in the cultivation container is the reduced density of seagrass on the cultivation container. Seagrass leaf has nutrients needed by sea cucumber sand for growth (Hair et al., 2011) so that seagrass is often used as additional food sea cucumber (Indriana et al., 2017). The lack of food intake causes sea cucumbers to eat seagrass so that the density decreases.

Through the $t$-test obtained results $\mathrm{T}_{\text {count }}(0.084)$ $<\mathrm{T}$ table (1.782). The value obtained indicates that both the cultivation container construction treatment performed have the same effect on the growth of body weight of sea cucumber.

\section{Water quality.}

Water quality is a very important environmental factor in a rearing system. Water quality affects the growth and survival of aquatic animals. The result of water quality parameter measurements during the research period is shown in Table 3.

The optimal water quality parameters for sea cucumber are $26-32^{\circ} \mathrm{C}$ (Andriyono et al., 2009), salinity 28-35 g/L (Indriana et al., 2017), $\mathrm{pH}$ 6.9-8.5 (Giraspy \& Walsalam, 2010), dissolved oxygen $>5.0 \mathrm{mg} / \mathrm{L}$ (Sulardiono et al., 2017), and turbidity $>40 \mathrm{~cm}$ (Komala, 2015). When compared to the water quality obtained during the experiment (Table 3), water quality during the experiment was within a good range for the survival rate of sea cucumbers.

Table 3. Water quality parameters during the research

\begin{tabular}{lccccccc}
\hline \multirow{2}{*}{ Month } & \multicolumn{7}{c}{ Water quality parameters } \\
\cline { 2 - 8 } & $\begin{array}{c}\text { Temperature } \\
\left({ }^{\circ} \mathrm{C}\right)\end{array}$ & $\begin{array}{c}\text { Salinity } \\
(\mathrm{g} / \mathrm{L})\end{array}$ & $\mathrm{pH}$ & $\begin{array}{c}\mathrm{DO} \\
(\mathrm{mg} / \mathrm{L})\end{array}$ & $\begin{array}{c}\text { Current } \\
(\mathrm{cm} / \mathrm{s})\end{array}$ & $\begin{array}{c}\text { Waves } \\
(\mathrm{m})\end{array}$ & Turbidity(cm) \\
\hline February & $29.3-29.5$ & $33-34$ & $7.2-7.8$ & $6.8-7.3$ & $11.7-20.3$ & $0.6-0.8$ & 160.0 \\
March & $29.2-29.3$ & $33-34$ & $7.4-7.5$ & $5.1-5.4$ & $10.8-19.5$ & $0.5-0.7$ & 140.0 \\
April & $29.1-29.2$ & $32-33$ & $7.3-7.4$ & $6.3-6.9$ & $18.9-23.7$ & $1.3-1.6$ & 100.0 \\
May & $31.2-31.3$ & $33-33$ & $7.3-7.9$ & $7.7-7.9$ & $37.0-45.4$ & $1.5-2.0$ & 104.0 \\
June & $28.3-29.3$ & $34-35$ & $7.9-8.1$ & $5.8-5.9$ & $37.3-48.2$ & $2.0-2.3$ & 105.0 \\
July & $29.6-31.0$ & $31-32$ & $7.5-7.8$ & $5.3-5.6$ & $25-35.2$ & $1.5-2.0$ & 95.0 \\
\hline
\end{tabular}




\section{CONCLUSION}

Based on the result of this research for sixmonths observation, it can be concluded that penculture of treatment $B$ was better applied in more open waters than the pen-culture of treatment A.

\section{ACKNOWLEDGEMENT}

The authors are grateful to Technician in Fisheries Rearing Studies Program, Tual State Fisheries Polytechnic, who has helped did data retrieval during this research so that this research can be done well.

\section{REFERENCES}

Andriyono S, Masithah E, Winarni D. 2015. The study of sea cucumber Phyllophorus sp. gonad histology: thermal shock to the spawning process. Journal of Natural Sciences Research 5: 101-105

Adipu Y, Lumenta C, Kaligis E, Sinjal HJ. 2013. Area suitability for mariculture in South Bolaang Mongondow regency, North Sulawesi. Jurnal Perikanan dan Kelautan Tropis $9: 19-26$

Agudo N. 2012. Pond grow-out trials for sandfish Holothuria scabra in New Caledonia. AsiaPacific tropical sea cucumber aquaculture ACIAR Proceedings 136: 104-112

Azam K, Singh JJ. 2013. Development of value added product from dried sea cucumber Holothuria scabra. Journal of Oceanography and Marine Research 1: 1-3

Bapeda. 2016. Environmental status and development of abalone Haliotis asinina in Western Kei Kecil district, Southeast Maluku regency. [Laporan]. Bapeda Maluku Tenggara.

Giraspy DAB, Walsalam IG. 2010. Aquaculture potential of the tropical sea cucumbers Holothuria scabra and $H$. lessoni in the Indo-Pacific region. SPC Beche-de-mer Information Bulletin 30: 29-32.

Hair C, Pickering T, Meo S, Vereivalu T, Hunter J, Cavakiqali L. 2011. Sandfish culture in Fiji Island. SPC Beche-de-mer Information Bulletin $31: 3-11$.

Hair C, Mills DJ, Mclntyer R, Southgate PC. 2016. Optimising methods for community based sea cucumber ranching: experimental releases of cultured juvenile, Holothuria scabra into seagrass meadows in Papua New Guinea. Aquaculture Reports 3 : 198-208

Indriana LF, Firdaus M, Suprono, Munandar H.
2017. Survival rate and growth of juvenile sandfish Holothuria scabra in various rearing conditions. Journal Marine Research in Indonesia 42: $11-18$.

Komala R. 2015. Diversity of sea cucumbers in seagrass and coral reefs ecosystem of Bira Besar Island, Kepulauan Seribu, Jakarta. Prosiding Seminar Nasional Masyarakat Biodiv Indon. $1: 222-226$.

Lavitra T, Rasolofonirina R, Jangoux M, Eeckhaut I. 2009. Problems related to the farming of Holothuria scabra (Jaeger, 1833). SPC Beche-de-mer Information Bulletin 20-27 pp.

Lavitra T, Rasolofonirina R, Eeckhaut I. 2010. The effect of sediment quality and stocking density on survival and growth of sea cucumber Holothuria scabra reared in nursery ponds and sea pens. Western Indian Ocean Journal of Marine Science 9: 153 - 164

Loupatty G. 2013.Characteristic of wave energy and current velocity of coastal area at Maluku Province. Jurnal Barekeng 7 : 19 - 22.

Namukose M, Msuya FE, Ferse SCA, Slater MJ, Kunzmann A. 2016. Growth performance of the sea cucumber Holothuria scabra and the seaweed Eucheuma denticulatum: Integrated mariculture and effects on sediment organic characteristics. Aquacult Environ Interact 8: 179-189.

Padang A, Sangadji M, Lukman E, Subiyanto R. 2017. Growth and the survival of sandfish Holothuria scabra reared in floating net cages. Jurnal TRITON $13: 115$ - 124.

Purcell S. 2012. Principles and science of stocking marine areas with sea cucumbers. Asia-Pacific tropical sea cucumber aquaculture. ACIAR Proceeding $136:$ 92-103.

Risandi J, Sagala SL, Pranowo WS. 2015. The application of wave characteristic numerical model for site selection of marine aquaculture development in Situbondo, East Java. Jurnal Kelautan Nasional. $10: 21-31$.

Serang, AM, Rahantoknam SPT, Tomatala P. 2016. Effect of different stocking densities on growth and survival rate of sea cucumber, Holothuria scabra seedlings. Journal Aquacultura Indonesia 17: 30 - 34.

Sulardiono B, Hendrarto B. 2014. Analysis of the density of sea cucumbers Holothurians based on the type of coral cover in Karimun Jawa Waters, Jawa Tengah. Jurnal Saintek Perikanan $10: 7-12$

Sulardiono B, Purnomo PW, Haeruddin. 2017. Environmental suitability for holothuroidea 
habitat in Karimunjawa. Jurnal Saintek Perikanan 12 : 93-97.

Tomatala P. 2014. Effectiveness of using frame net in spacing process of pearl oyster seeds Pinctada maxima. Jurnal Budidaya Perairan 2 $: 1-6$.
Windupranata. 2007. Development of a decision support system for suitability assessment of mariculture site selection. [Disertasi]. Coastal Engineering and Geoscience, University of Kiel Germany. 